\title{
COMMUNICATION
}

\section{HEALTH EDUCATION IN CHAGAS DISEASE CONTROL: MAKING AN EDUCATIONAL VIDEO}

\author{
Tanise Freitas Bianchi ${ }^{1}$, Cibele Velleda dos Santos ${ }^{1}$, Sabrina Jeske ${ }^{1}$, Ana Paula \\ Grala $^{1}$, Micaele Quintana de Moura ${ }^{1}$, Diego Santos Madia ${ }^{2}$, Rafael Martins ${ }^{2}$, \\ Tania Stasiak Wilhelms ${ }^{3}$, Cleonara Bedin ${ }^{3}$, Francele de Abreu Carlan ${ }^{4}$ and \\ Marcos Marreiro Villela ${ }^{1}$
}

\begin{abstract}
Several studies have shown that the population has relatively little information regarding Chagas disease (CD) and its vectors; however, this knowledge is relevant because community participation is vital for success in disease control actions. For this reason, and due to the lack of audiovisual material on this subject in the country, this study focused on making an educational documentary on $\mathrm{CD}$ and its vectors, which could be available to the population for free. The video preparation was divided into three phases: Pre-production, Production and Post-production. The site chosen for shooting was northwestern Rio Grande do Sul State due to the Triatoma infestans vector persistence in recent decades in that area. A documentary was obtained which addresses relevant $\mathrm{CD}$ aspects, such as its history, transmission, major vectors and biology, phases of the disease and, in particular, how to inspect the intra-domiciliary and peri-domiciliary areas in search of triatomine bugs or "kissing bugs". The use of videos as an educational tool helps broadcast information; therefore, this documentary is a public use tool, which aims to promote the control and prophylaxis of $\mathrm{CD}$ and its vectors.
\end{abstract}

KEY WORDS: Chagas disease; Trypanosoma cruzi; educational documentary

Chagas disease $(\mathrm{CD})$ is a serious public health hazard in Latin America, where it is estimated that more than 10,000 people die annually due to clinical manifestations of the disease, and around 25 million individuals are at risk of infection (Ostermayer et al., 2011; WHO, 2017; Ribeiro et al., 2014).

Nevertheless, studies have shown that there are still gaps in the population's awareness regarding $\mathrm{CD}$, not only in relation to its transmission but also its prevention and control. This lack of information contributes to CD being one of the most neglected tropical diseases in the world; in addition, the

\footnotetext{
1. Programa de Pós-Graduação em Parasitologia, Instituto de Biologia, Universidade Federal de Pelotas (UFPel), Pelotas, Rio Grande do Sul, Brazil.

2. Núcleo Telessaúde Universidade Federal do Rio Grande do Sul, Porto Alegre, Rio Grande do Sul, Brazil.

3. Centro Estadual de Vigilância em Saúde, SES/RS, Porto Alegre, Rio Grande do Sul, Brazil.

4. Programa de Pós-Graduação em Ensino de Ciências e Biologia, UFPel, Pelotas, Rio Grande do Sul, Brazil.

Corresponding author: Tanise Freitas Bianchi. E-mail: tanisebianchi@hotmail.com
}

Received for publication: 3/5/2018. Reviewed: 6/7/2018. Accepted: 7/7/2018. 
lack of educational material for public distribution has already been reported by Chagas Disease Control Program agents (Sanmartino \& Crocco, 2000; Dias et al., 2002; Villela et al., 2007).

Educational videos are used as a basis for information on social intervention actions in the health field since they are considered information transfer facilitators (Alves, 2005; Moraes, 2008).

With reference to $\mathrm{CD}$ control, disease vector surveillance measures should be reinforced through educational actions developed within the community. Based on the lack of audiovisual material on this theme and the relevance of monitoring the disease in the country, this study aimed to develop an educational documentary on CD and its vectors based on housing improvement and rural home environment management by focusing on important aspects of the disease, such as its prevention and control.

This study included the preparation of digital educational technology developed according to Kindem \& Musburger (2005), which specifies the necessary phases for the development of an educational video: Pre-production, Production and Post-production. Pre-production: this is the phase that aims to prepare, plan and design the video itself, including all the steps that must be taken from the initial idea to the shooting (Kindem \& Musburger, 2005). The development of this video was an integral part of the Impact Assessment of Housing Improvements for Chagas Disease Control Project (Santos et al., 2016) where a partnership was established between researchers from the Federal University of Pelotas (UFPel), the Rio Grande do Sul State Center for Health Surveillance (CEVS-RS) and Telessaúde/RS-UFRGS, for the documentary audiovisual development. The study was approved by the Ethics Committee under ruling 287,362, and obtained financial support from $\mathrm{CNPq}$ under number: 467104/2014/Call n. 31/2014, Chagas Disease Research.

The script, defined in this phase included detailed shooting structure and encompassed the topics: CD discovery; vector species in Rio Grande do Sul state (shooting set) and their evolutionary phases; disease transmission; search for triatomine bugs in housing units (HU, consisting of the house and its annexes) and housing improvements; major CD clinical manifestations; documentary closing. The script was reviewed by all project participants.

Production: the phase in which scenes and audios were recorded; the shooting set chosen was northwestern Rio Grande do Sul State due to the Triatoma infestans vector persistence in that area in recent decades, and also because the area was allotted financial resources through a National Health Foundation (FUNASA) agreement for the Housing Improvement Program for Chagas Disease Control (HIPCDC), one of the topics addressed in the documentary.

Post-production: the last phase in which the editing and organization of the recorded footage of the entire video was performed (Kindem \& Musburger, 2005). The video was edited and organized into different takes, 
and the necessary cuts and audio synchronization to be inserted into the main timeline were done for each sequence. The Adobe Premiere CC ${ }^{\circledR}$ software was used for editing the video, and animations were included through Adobe Animate $C C \circledR$. For the audio, the Logic Pro ${ }^{\circledR}$ and Adobe Audition ${ }^{\circledR}$ software was used. After the initial cut was assembled, the Documentary exclusive copyright soundtrack was produced.

The Documentary was concluded only after a comprehensive analysis and evaluation of the digital learning tool had been performed. Subsequently, the film was recorded on DVD, and copies were distributed free of charge to the population via Basic Health Units and Municipal Health Departments; access to its content was also made available free through the YouTube ${ }^{\circledR}$ channel.

The documentary begins with a musical soundtrack and rural environment images including dogs, cattle, landscape, this creating a relevant atmosphere for the theme. The narrator appears, filmed at American shot angle, saying, "Hello, what do you know about Chagas disease?" Following, a report is presented on the $\mathrm{CD}$ discovery by a human parasitology professor, briefly telling the story of how the Brazilian researcher Carlos Chagas described aspects of the disease and its vectors.

Next, a parasitology graduate student addresses the evolutionary forms of triatomine bugs, their life cycle (showing insect eggs, its five nymphal stages, and adults in a showcase), and some triatomine species, with a brief description of their chromatic and behavioral differences. Triatoma rubrovaria, Triatoma infestans and Panstrongylus megistus were characterized. Table shows the topics covered by the documentary and the duration of each phase.

Next, a Health Surveillance monitoring team is shown doing fieldwork, instructing viewers on how to carry out an inspection inside houses and peridomiciliary areas (Figure, images $\mathrm{A}$ and $\mathrm{B}$ ). The team teaches how to identify triatomine bug traces; in order to do so the major places where triatomines can be found and the inspection of an intradomiciliary environment by a public health agent, looking for vectors behind frames and calendars, cracks, clothes and mattresses, are shown. Next, searches are shown in peridomiciliary areas, chicken coops, a stone pile, tile and firewood heaps, among other places that might serve as vector hiding places or that contain animal nests which could serve, in turn, as food sources for triatomines. The shooting concentrates on searches and explanations as to the presence of triatomines, especially in peridomiciliary areas (Table).

After the vector and surveillance approach, the presenter returns and discusses the oral transmission of the disease, mainly with açai and sugarcane juice. Other modes of transmission, such as blood transfusion, organ transplants, congenital transmission, and ingestion of raw or undercooked game, are explained by a parasitology graduate student. 
Table. Topics covered by the Chagas disease documentary including duration of each phase.

\begin{tabular}{|c|c|}
\hline Duration & Content addressed \\
\hline $0 ’ 45^{\prime \prime}$ & $\begin{array}{l}\text { Opening with logos of units involved in the project, } \\
\text { then the title "Chagas Disease Documentary" appears } \\
\text { showing rural environment images in the background } \\
\text { with a musical soundtrack. }\end{array}$ \\
\hline $0 ’ 46 ”-1 ’ 06 ”$ & $\begin{array}{l}\text { The narrator introduces the video by asking: "What } \\
\text { do you know about Chagas disease? }\end{array}$ \\
\hline $1 ’ 07 ',-3 ’ 29 ’$ & A sunset is shown and then CD discovery is reported. \\
\hline 3’30’'-4’30”' & $\begin{array}{l}\text { Dawn in the countryside and comment on the } \\
\text { hematophagous habits of the triatomine bug. } \\
\text { Laboratory shot addressing the evolutionary forms of } \\
\text { triatomines and their life cycle. }\end{array}$ \\
\hline 4’31"'-5’09”' & $\begin{array}{l}\text { Still in the laboratory, major triatomine species } \\
\text { captured in Rio Grande do Sul state are shown. }\end{array}$ \\
\hline 5'10’-7’0”, & $\begin{array}{l}\text { A health surveillance team is followed in an } \\
\text { introdomiciliary area survey. }\end{array}$ \\
\hline 7’01"'-8'06"' & $\begin{array}{l}\text { Report on one of the last Triatoma infestans foci, } \\
\text { which occurred in the lining of a church located in the } \\
\text { municipality of Santo Cristo, RS, including reports } \\
\text { by agents who fought to eradicate vectors. }\end{array}$ \\
\hline 8'07',-9’30”, & $\begin{array}{l}\text { Visit to one of the houses benefited by the Housing } \\
\text { Improvement Program for CD Control, with } \\
\text { explanations by the architect who participated in } \\
\text { designing and executing the program in Rio Grande } \\
\text { do Sul. }\end{array}$ \\
\hline 9'31”-13'51”, & $\begin{array}{l}\text { Inspection of the peridomiciliary area of a rural } \\
\text { property. }\end{array}$ \\
\hline $13 ' 522^{\prime}-15^{\prime} 33^{\prime} \prime$ & Modes of CD transmission and epidemiological data. \\
\hline $15 ’ 34 ’-19 ’ 47 ”$ & CD clinical phases and complications. \\
\hline $19 ’ 48 ’-20 ’ 28 ”$ & Comment on $\mathrm{CD}$ vector surveillance. \\
\hline 20’29”-21’30”, & Project Credits. \\
\hline
\end{tabular}




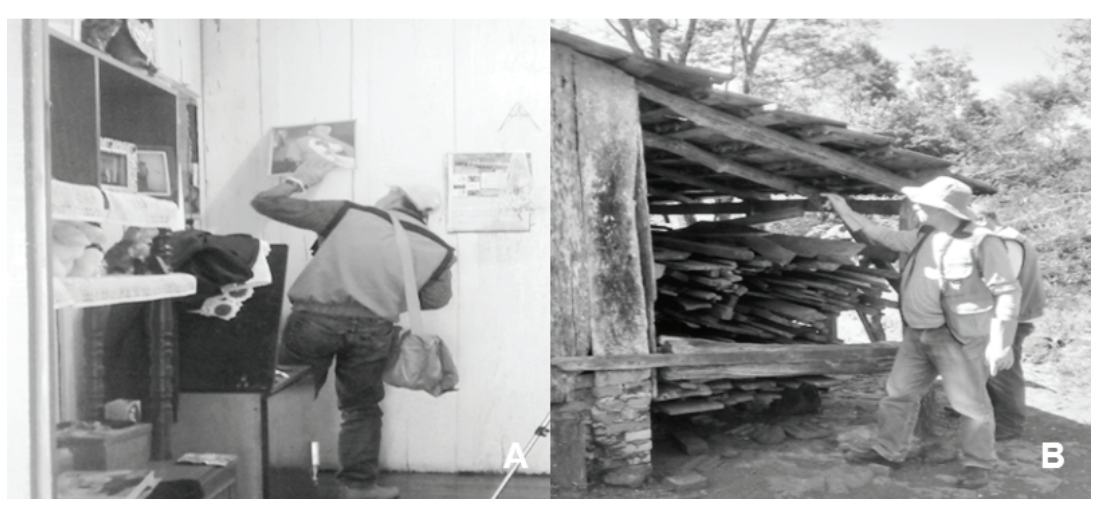

Figure. (A) Inspection inside the residence by the health surveillance agent. (B) Inspection of the annexes of the residence (peridomiciliary) by the health surveillance agent.

Subsequently, the parasitology professor is again interviewed to report aspects of CD phases and complications. During his talk, the researcher explains that $\mathrm{CD}$ usually goes unnoticed or manifests itself through fever and other unknown specific signs in its acute phase. It is also explained that about half of the individuals reaching the chronic phase may develop the chronic cardiac and/or digestive conditions, and both forms of the disease are discussed. The video is concluded with the narrator's comment on $C D$ vector surveillance and the paramount importance of the participation of every community in controlling the disease.

The documentary is available free on the internet (https://www. youtube.com/watch? $\mathrm{v}=\mathrm{x} 7 \mathrm{RqdQB} 7 \mathrm{XjA}$ ) and also in DVD copies, and lasts $21 \mathrm{~min} 31 \mathrm{sec}$. The video has already been shown to the general population at community meetings, school activities, Basic Health Units, and in health worker training or refresher courses. It has been reported that, nine months after being made available on the Internet, the documentary has had more than 9,000 viewings.

This documentary was produced in order to clarify major doubts on $\mathrm{CD}$ and its vectors, and is a new tool in its control, especially when used in surveillance activities and educational meetings with the community.

The information contained in the film was presented in a simple and direct way so that people could understand its content, thus limiting the possibility of misinterpretations on the subject. As the video has rural area dwellers as its target audience, the use of technical and formal expressions was avoided, which undoubtedly aided concept and knowledge transfer. At the very beginning, the question "What do you know about Chagas disease?" is asked. Throughout the documentary, a musical background and animated effects were used. The use of questions as well as audiovisual techniques helps arouse the 
viewer's curiosity on the subject and message memorization, in addition to drawing the audience's attention more quickly (Luz et al., 2003).

$\mathrm{CD}$ history is shown in the video and was included because this was a relevant discovery made by a Brazilian doctor which is thought to be a breakthrough in the history of medicine (Malafaia \& Rodrigues, 2010). Subsequently, the vectors and their biological cycles are also shown, with some of the species being exemplified. The triatomine T. rubrovaria is pointed out as being the most commonly captured species in Rio Grande do Sul in recent decades (Almeida et al., 2000; Priotto et al., 2014); however, T. infestans is also emphasized, since there are still residual foci of this triatomine in some municipalities in northwestern of Rio Grande do Sul (Bedin et al., 2009), even though it has been practically eliminated elsewhere in Brazil. The persistence of these foci is probably due both to vector biology and the cultural practice of gathering materials in the peridomiciliary area annexes, especially firewood, boards and lumber (D'avila Pessoa et al., 2015).

$\mathrm{CD}$ transmission via vector spreads more rapidly in places that present favorable conditions for the development of triatomines, with the presence of cracks and food sources, as is the case of peridomiciliary areas. Due to this, a large part of the documentary focused on the search for and explanations of the occurrence of triatomines in the peridomiciliary environment, inasmuch as the entomological surveillance with the help of the community is today the main strategy for the control of CD vector transmission (Dias et al., 2016). According to Oliveira-Lima et al. (2000), house annexes are more colonized by vectors, especially animal shelters and piles of tiles, bricks and firewood, locations where there is also triatomine occurrence (Sarquis et al., 2012; Bezerra et al., 2014).

It is important to explain how to search for triatomines in a housing unit in a practical way so as to obtain effective participation by the population in vector notification. This is one of the few videos to show how this search may be performed in loco. According to Silva et al. (2003), community participation in triatomine capture is an effective mechanism, since it selects the house units to be investigated and entails a lower cost to the state. This, in spite of the efforts made by control programs in Latin America, is not always able to cover all houses and communities (Echeverria et al., 2017; Moreno \& Baracho, 2000). It is noteworthy that, in addition to its use by the population, the documentary is also being used to train new health agents, who are to work in endemic disease control, since it is known that there are training shortcomings for these workers, especially after the health decentralization which reorganized the municipal Chagas Disease Control Program (CDCP) (Villela et al., 2009). In addition, it was verified that the agents were not being provided with more informative tools for the general population (Alves, 2005). 
Next, field approach, modes of transmission and epidemiology of the disease were focused on, and different $\mathrm{CD}$ modes of transmission were mentioned apart from the vector, such as the oral, congenital and transfusion pathways (the latter now less common due to greater blood bank control) (Dias, 2006). In this sense, emphasis should be placed on the possibility of oral transmission, which has been the prevailing mode of transmission in Brazil in recent years (Dias et al., 2011). Although the highest frequency of this kind of transmission is in northern Brazil, the first outbreaks most likely due to T. cruzi oral transmission occurred in Rio Grande do Sul State (Silva et al., 1968; Di Primio, 1971).

CD complications and phases were also discussed. In the acute phase, it is pointed out that the specific antiprotozoal drug should be used for greater efficacy; however, this does not occur in most cases, and due to the scarcity of characteristic signs or symptoms, CD acute phase often goes unnoticed (Rassi \& Marin-Neto, 2010; Coura, 2007; Coura \& Viñas, 2010). The chronic phase was also presented in its undetermined and determined (symptomatic) forms, with emphasis on megas and heart failure (Dias, 1995; Gascón, 2007; Steverding, 2014). Given the difficulty and high treatment costs during the chronic phase of the condition, the video emphasizes the relevance of disease control and prophylaxis.

Finally, the presenter reemphasizes the importance of $\mathrm{CD}$ vector surveillance and the closing credits of the film appear. Thus, after the viewing and analysis of the documentary, it can be concluded that the development of the video as an educational tool increases awareness, since the information contained in this audiovisual media reaches the population in general, increasing the understanding on certain topics approached correctly. Therefore, it is believed that this documentary represents a new tool for public use aiming to promote the control/prophylaxis of $\mathrm{CD}$ and its vectors.

\section{REFERENCES}

1. Almeida CE, Vinhaes MC, Almeida JR, Silveira AC, Costa J. Monitoring the domiciliary and peridomiciliary invasion process of Triatoma rubrovaria in the State of Rio Grande do Sul, Brazil. Mem Inst Oswaldo Cruz 95: 761-768, 2000.

2. Alves VS. Um modelo de educação em saúde para o Programa Saúde da Família: pela integralidade da atenção e reorientação do modelo assistencial. Interface Comunic Saude Educ 9: 39-52, 2005.

3. Bedin C, Mello F, Wilhelms TS, Torres MA, Estima C, Ferreira CF, Sehn L. Vigilância Ambiental: Doença de Chagas no Rio Grande do Sul. Secretaria da Saúde do Rio Grande do Sul. Boletim Epidemiol CEVS/RS 11: 1-8, 2009.

4. Bezerra CM, Cavalcanti LPDG, Souza RDCMD, Barbosa SE, Xavier SCDC, Jansen AM, Ramalho RD, Diotaiuti L. Domestic, peridomestic and wild hosts in the transmission of Trypanosoma cruzi in the Caatinga area colonised by Triatoma brasiliensis. Mem Inst Oswaldo Cruz 109: 887-198, 2014. 
5. Coura JR. Chagas disease: what is known and what is needed. A background article. Mem Inst Oswaldo Cruz 102: 113-122, 2007.

6. Coura JR, Viñas PA. Chagas disease: a new worldwide challenge. Nature 465: S6-S7, 2010.

7. D'avila Pessoa GC, Rosa ACL, Bedin C, Wilhelms T, Mello F, Coutinho HS, Fonseca EOL, Santos RF, Diotaiut L. Susceptibility characterization of residual Brazilian populations of Triatoma infestans Klug, 1834 (Hemiptera: Reduviidae) to deltamethrin pyrethroid. Rev Soc Bras Med Trop 48: 157-161, 2015.

8. Di Primio R. Erros e deficiências no diagnóstico de doença de Chagas no Rio Grande do Sul. O problema da provável contaminação por via oral do Trypanosoma cruzi em Teutônia, RS. $O$ Hospital 80: 150-165, 1971.

9. Dias JCP. Doença de Chagas e transfusão de sangue no Brasil: vigilância e desafios. Rev Bras Hematol Hemoter 28: 81-87, 2006.

10. Dias JCP. Natural history of Chagas disease. Arq Bras Cardiol 65: 359-366, 1995.

11. Dias JCP, Amato Neto V, Luna EJDA. Mecanismos alternativos de transmissão do Trypanosoma cruzi no Brasil e sugestões para sua prevenção. Rev Soc Bras Med Trop 44: 375-379, 2011.

12. Dias JVL, Queiroz DRM, Diotaiuti L, Pires HHR. Knowledge of triatomine insects and of the Chagas disease among people from localities which have different levels of vector infestations. Cien Saude Colet 21: 2293-2304, 2016.

13. Dias JCP, Silveira AC, Schofield C. The impact of Chagas disease control in Latin America: a review. Mem Inst Oswaldo Cruz 97: 603-612, 2002.

14. Echeverria JE, Rodriguez AN, Cortez MR, Diotaiuti LG, Gorla DE. Spatial and temporal distribution of house infestation by Triatoma infestans in the Toro Toro municipality, Potosi, Bolivia. Parasit Vectors 10: 58-65, 2017.

15. Gascón J, Albajar P, Cañas E, Flores M, i Prat JG, Herrera RN, Lafuente CA, Luciardi HL, Moncayo A, Molina L, Muñoz J, Puente S, Sanz G, Treviño B, Salles XS. Diagnóstico, manejo y tratamiento de la cardiopatía chagásica crónica en áreas donde la infección por Trypanosoma cruzi no es endémica. Rev Esp Cardiol 60: 285-293, 2007.

16. Kindem GA, Musburger RB. Introduction to Media Production: from analog to digital. 3rd ed. Boston, Focal Press, 2005. 532p.

17. Luz ZMPD, Pimenta DN, Rabello A, Schall V. Evaluation of informative materials on leishmaniasis distributed in Brazil: criteria and basis for the production and improvement of health education materials. Cad Saude Publica 19: 561-569, 2003.

18. Malafaia G, Rodrigues, ASDL. Centenário do descobrimento da doença de Chagas: desafios e perspectivas. Rev Soc Bras Med Trop 43: 483-485, 2010.

19. Moraes AFD. Cultural diversity in health-related videos. Interface Comunic Saude Educ 12: 811-822, 2008.

20. Moreno EC, Baracho L. Vigilância epidemiológica no Programa de Controle da Doença de Chagas em Minas Gerais, Brasil (1984-1998). Cad Saude Publica 16: 113-116, 2000.

21. Oliveira-Lima JW, Faria Filho OF, Vieira JBF, Gadelha FV, Oliveira Filho AM. Alterações do peridomicílio e suas implicações para o controle do Triatoma brasiliensis. Cad Saude Publica 16: 75-81, 2000.

22. Ostermayer AL, Passos ADC, Silveira AC, Ferreira AW, Macedo V, Prata AR. O inquérito nacional de soroprevalência de avaliação do controle da doença de Chagas no Brasil (20012008). Rev Soc Bras Med Trop 44: 108-121, 2011.

23. Priotto MCM, Santos CV, Mello F, Ferraz LM, Villela MM. Aspectos da vigilância entomológica da doença de Chagas no sul do Rio Grande do Sul, Brasil. Rev Patol Trop 43: 228-238, 2014.

24. Rassi A, Marin-Neto JÁ. Chagas disease. Lancet 375: 1388-1402, 2010. 
25. Ribeiro AR, Mendonça VJ, Alves RT, Martinez I, Araújo RFD, Mello F, Rosa JÁ. Trypanosoma cruzi strains from triatomine collected in Bahia and Rio Grande do Sul, Brazil. Rev Saude Publica 48: 295-302, 2014.

26. Sanmartino M, Crocco L. Conocimientos sobre la enfermedad de Chagas y factores de riesgo en comunidades epidemiológicamente diferentes de Argentina. Rev Panam Salud Publica 7: 173-178, 2000.

27. Santos CVD, Bedin C, Wilhelms TS, Villela MM. Assessment of the Housing Improvement Program for Chagas Disease Control in the Northwestern municipalities of Rio Grande do Sul, Brazil. Rev Soc Bras Med Trop 49: 572-578, 2016.

28. Sarquis O, Carvalho-Costa FA, Toma HK, Georg I, Burgoa MR, Lima MM. Eco-epidemiology of Chagas disease in northeastern Brazil: Triatoma brasiliensis, T. pseudomaculata and Rhodnius nasutus in the sylvatic, peridomestic and domestic environments. Parasitol Res 110: 1481-1485, 2012.

29. Silva ND, Clausell DT, Núbilos H, Mello AL, Ossanai J, Rapone T, Snell T. Surto epidêmico de doença de Chagas com provável contaminação oral. Rev Inst Med Trop 10: 265-276, 1968.

30. Silva RAD, Rodrigues VLC, Carvalho MED, Pauliquévis Jr C. Programa de controle da doença de Chagas no Estado de São Paulo: persistência de alta infestação por triatomíneos em localidades na década de 1990. Cad Saude Publica 19: 965-971, 2003.

31. Steverding D. The history of Chagas disease. Parasit Vectors 7: 317-324, 2014.

32. Villela MM, Pimenta DN, Lamounier PA, Dias JCP. Avaliação de conhecimentos e práticas que adultos e crianças têm acerca da doença de Chagas e seus vetores em região endêmica de Minas Gerais, Brasil. Cad Saude Publica 25: 1701-1710, 2009.

33. Villela MM, Souza JMBD, Melo VDP, Dias JCP. Vigilância epidemiológica da doença de Chagas em programa descentralizado: avaliação de conhecimentos e práticas de agentes municipais em região endêmica de Minas Gerais, Brasil. Cad Saude Publica 23: 2428-2438, 2007.

34. World Health Organization. WHO. 2017. Neglected tropical diseases. Available from: http:// www.who.int/neglected_diseases/diseases/en/. Access to: March, 2017. 